\title{
ANALYSIS AND DESIGN OF E-LEARNING SYSTEM PROTOTYPE FOR LIFELONG LEARNING IN BHUTAN
}

\author{
Chimi Wangmo, Galina Ivanova \\ Department of Computing, University of Ruse, Bulgaria \\ 8 Studentska Str., Ruse 7017, Bulgaria \\ phone: +359 82 888855, e-mail: chim3yy@gmail.com, givanova@ecs.uni-ruse.bg
}

\begin{abstract}
The paper reviews the existing e-learning system implemented in Bhutan and discuses some problems of existing solution. A new system for lifelong learning specifically for education of Bhutanese people is presented. The paper discusses the objectives and the accomplished features of a new lifelong e-learning prototype - Bhutanese e-learning system. It is a prototype that can be customized to perform versatile functionalities to engage students and improve their participation. The system also serves as a basic student information system providing details of student, however, development and integration of other functionalities like result management system can be an asset.
\end{abstract}

Keywords: lifelong learning, distance learning, e-learning, responsive online system.

\section{INTRODUCTION}

Bhutan realizes the concept of distance education system and is motivated to employ it as the rest of the world [5]. In present time, Royal University of Bhutan is the only university in Bhutan. 10500 students attempted BHSEC (Bhutan Higher Secondary Education Council) examination in 2017, out of which only 2507 were admitted to Royal University of Bhutan with scholarship. The rest of the students applied outside the country to receive degree or diploma education. These tuitions were considerably expensive apart from the living and travelling expenses.

The distance learning lifelong programme could address numerous expenditures and benefit students to acquire skills and certification by studying online within the country.

\section{VIRTUAL LEARNING ENVIRONMENT IN BHUTAN}

In 2011 with the funding of World Bank and support of expertise from University of Colombo School of Computing, Royal University of Bhutan has implemented Moodle based e-learning system in ten of its colleges [7]. The established learning system is called Virtual Learning Environment (VLE). Each college has established its own VLE incorporating study programmes and respective taught courses. Currently these VLEs are not connected to each other and the center university management is not effective.

VLE in Bhutan based on Moodle also have some problems with the speed of internet connection [8]. Currently the fastest internet speed available in Bhutan is 1.5Mbps. The Internet structure is heavily relied on telephone networks like broadband and modems. The access to internet from mobile phones has sporadic coverage across the country. Moodle system is complex and apart from providing the important services, it supports advanced but unnecessary functionalities which require higher internet bandwidth. Therefore this system is unproductive. 


\section{ARTTIE $Y$}

Ipplied Resseirlores in Technics, Technologies and Educration

Journal of the Faculty of Technics and Technologies, Trakia University https://sites.google.com/a/trakia-uni.bg/artte/

Moodle is a complex environment and requires numerous training and professional development programs to enhance the competencies of both staffs and students [6]. The training is expensive and also time consuming.

Presently, the implemented VLE Moodle system does not support Dzongkha language rendering and the users have to know English to use the system. In this way, incompetent users do not have opportunity to acquire new skills and knowledge.

\section{LIFELONG E-LEARNING SYSTEM PROTOTYPE}

The emerging new prototype of lifelong e-learning system is designed and hence developed. The prototype has an aim of addressing the factors mentioned above impeding the dissipation of information and encouraging interactive learning environment through easy to use interface. The web based e-learning system targeting Bhutanese education system has become crucial. This system is a platform for emerging continuous advanced learning programme that could prepare an individual skill for particular job. It can also serve to ensure effective distance learning environment. Bhutan does not have such platform or programme associated with lifelong learning and thus, is limited to university face to face learning and training courses provided by few, small institutes.

\section{METHODOLOGY FOR SOFTWARE REALIZATION}

Agile methodology is identified to be suitable for the proper completion of this software framework development.

During the first phase, a comprehensive analysis and study of various existing e-learning platform, both free and vendor based is successfully completed. A report is produced, consisting of approaches and intensive research on the functionalities provided by popular platforms such as moodle [4], talentLMS [9,11], canvas [10,12] and etc [1]. Additionally, an analysis of e-learning system in University of Ruse called E-learning Shell has also been analyzed and added to the report [3]. The significance and drawbacks were concluded, which was used in gathering of functional requirements to design the new system for lifelong learning.

Functional requirements are well documented in system requirement specification. The main goals of this system are summarized in the following points:

i. It should offer customizable structure for course, department and programme in order to facilitate different universities and private institute's structure.

ii. It should provide user Management feature governing to the Guest Users, Student and Tutors.

iii. Includes unique Bhutanese Grading system for assessment of quiz and assignments results.

iv. Ensure easy to use and responsive websites that will adjust according to the screen of the device.

v. Provide communication environment to share and comment on study topics in the form of forum or chat.

\section{ROLES AND RESPONSIBILITIES}

i. System Administrator/Admin: The system administrator will be able to perform the following functions:

- edit his own profile (credentials and personal details);

- view the list of pending users and approve user registration with tutor or student permission;

IRTIIE Vol. 5, No. 4, 2017 ISSN 1314-8788 (print), ISSN 1314-8796 (online), doi: 10.15547/artte.2017.04.007 


\section{ART'TE \\ ( \\ Ipplied Resseirlohes in Technics, Technologies and Eductition \\ Journal of the Faculty of Technics and Technologies, Trakia University https://sites.google.com/a/trakia-uni.bg/artte/}

- have privileges to activate or deactivate course or user, if and when required;

- create, edit or delete department structure and add or remove programmes;

- create, edit or delete course structure and assign learning resources;

- define course activities (forum, quizzes, chat, assignments, etc);

- monitors users and oversees variety of department and course's activities;

- trains department personnel and students to use the online web application.

ii. Tutors: Can perform the following functions:

- enable manual self-registration and redirection to guest user's dashboard;

- access tutors' dashboard after admin approves registration;

- view and update his own profile (sign in credentials and personal details);

- view registered student and add or remove one or group of students to the course;

- view students' report and provide remarks;

- create course and set an unique enrollment key;

- create, edit or delete course structure and assign learning resources;

- define course activities (forum, quizzes, chat, assignments, etc);

- display teaching feedback.

iii. Students: The students are regular student or special student for short term training.The student users are permitted to perform following functions:

- enable manual self-registration and redirection to guest user's dashboard;

- access students'dashboard after admin approves registration;

- view and update his own profile (sign in credentials and personal details);

- view all the list of courses and their description;

- subscribe to the courses after entering unique enrollment key and then view course's assigned content resources;

- participate in discussion forum and chat;

- test the knowledge of subject through attempting numerous quizzes;

- view grades and remarks from tutor;

- provide feedbacks to tutor.

\section{SOFWARE DESIGN AND LAYOUTS}

A flowchart that shows the basic process for accessing individual dashboards by Admin and users is presented on Figure 1.

Admin and user (Tutor or student) need to login with proper credentials. Depending on whether Admin has approved user as Student or Tutor, user will be redirected to relevant dashboard.

Every new user is admitted with guest user's privilege initially. It is extremely essential for user (student and tutor) to provide correct student and tutor number as username along with email to ensure registration.

The administrator will evaluate the pending list of users and depending on the correct username authentication provided, user either is approved or denied.

If the user is not approved as Student or Tutor or doesn't match their authentication details, they cannot login to the system.

If the authentication matches, for instance, Tutor has access to the course he has created and can assign learning resource materials. Tutor can view all the student registrant and can add more students to the created course. Tutor creates and shares the unique enrollment key to his course.

Students can only view list of courses and the content to the courses, student is enrolled into. In order to enroll to new course, student needs to enter correct enrollment key provided by the tutor. Student can participate in various activities like quizzes and forum. Submission of 


\section{AR'IIE}

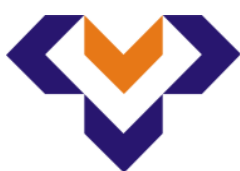

Ipplied Resererr'ches in Technics, Technologies ind Bduration

Journal of the Faculty of Technics and Technologies, Trakia University https:///ites.google.com/a/trakia-uni.bg/artte/

assignment is also permitted. Student can view his performance report on his participation in learning activities and also display remarks from tutor.

Admin manages user and its role assignment. Admin can display the list of courses and its detail information. Admin enables tutor and student's admission and support them in troubleshooting simple account usage problem. They monitor users and oversee variety of department and course's activities. Admin trains department personnel and students to use the web application.

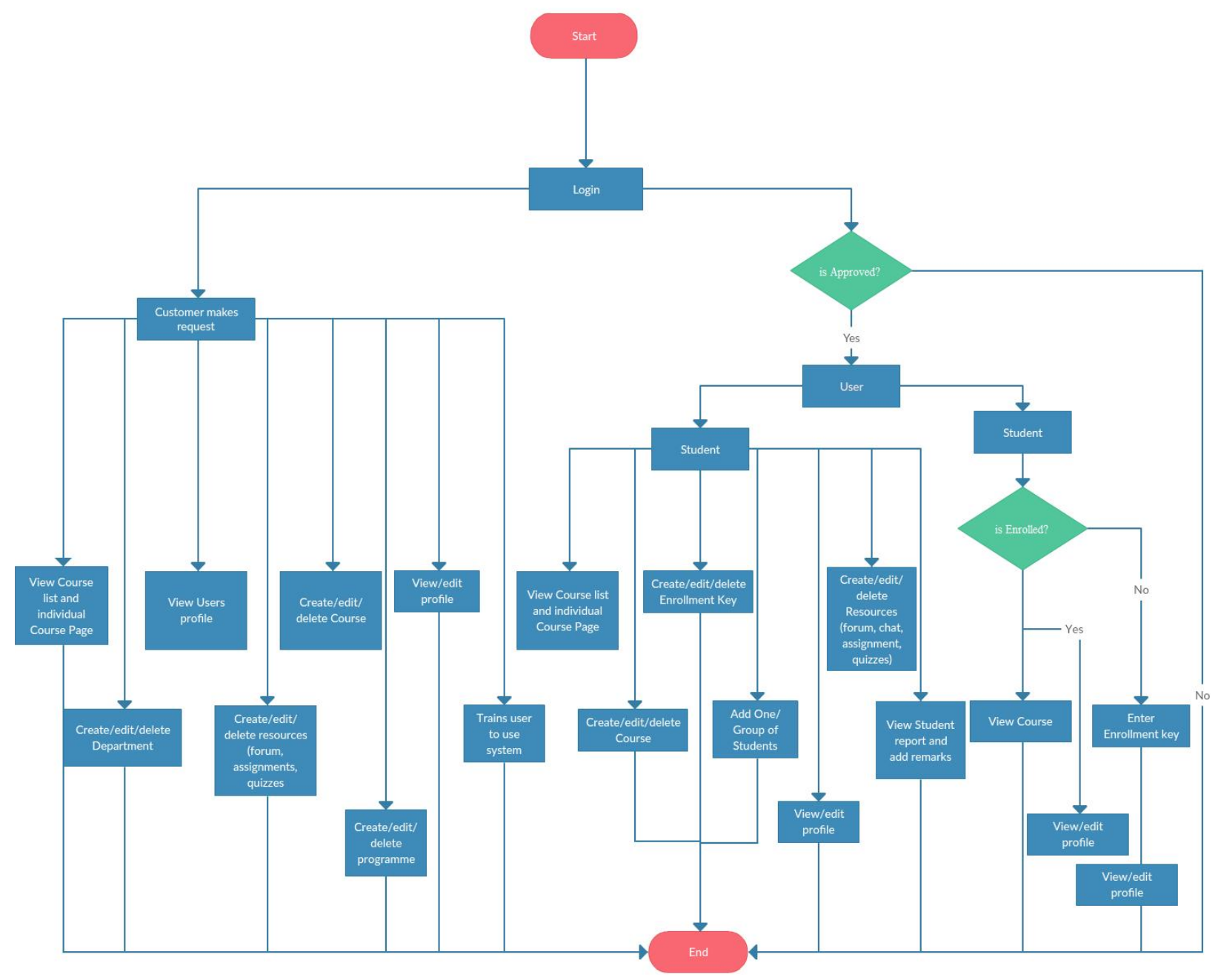

Figure 1. Flow Diagram

\section{SOFTWARE REALIZATION}

After analyzing various framework, Laravel framework is concluded to best suit the development of the e-learning model-view-controller web application. The system employs the usage of laravel framework version 5.4 [13] and its packages, bootstrap for developing responsive, css styling of the websites. It uses mysql version 5.7.1 for system database. The programming language used to develop the interactive system are PHP, HTML and JavaScript.

The admin dashboard providing management and administration of user, courses, programmes, department, results and the content resources is represents on Figure 2. As

IRTIIE Vol. 5, No. 4, 2017 ISSN 1314-8788 (print), ISSN 1314-8796 (online), doi: 10.15547/artte.2017.04.007 


\section{IRTIIE}

Ipplied Resererr'ches in Technics, Technologies and Bduration

Journal of the Faculty of Technics and Technologies, Trakia University https:///ites.google.com/a/trakia-uni.bg/artte/

shown on the Figure 3 the system provides simplified course list with edit and delete action buttons. It does not require a person to be computer elite now to create and share learning materials. An individual does not need to remember the complex mechanism and thus, Bhutanese individual unfamiliar with computer application can simply access public resources easily with one click of button.

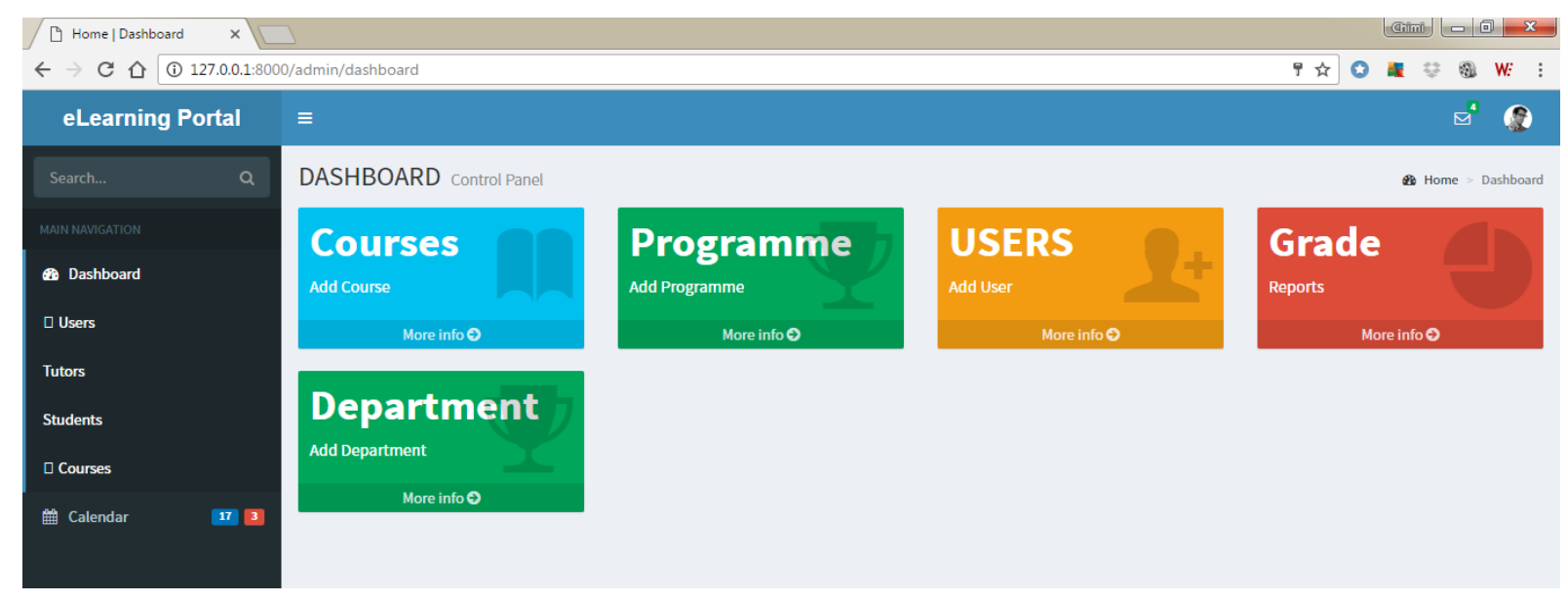

Figure 2. Admin Dashboard

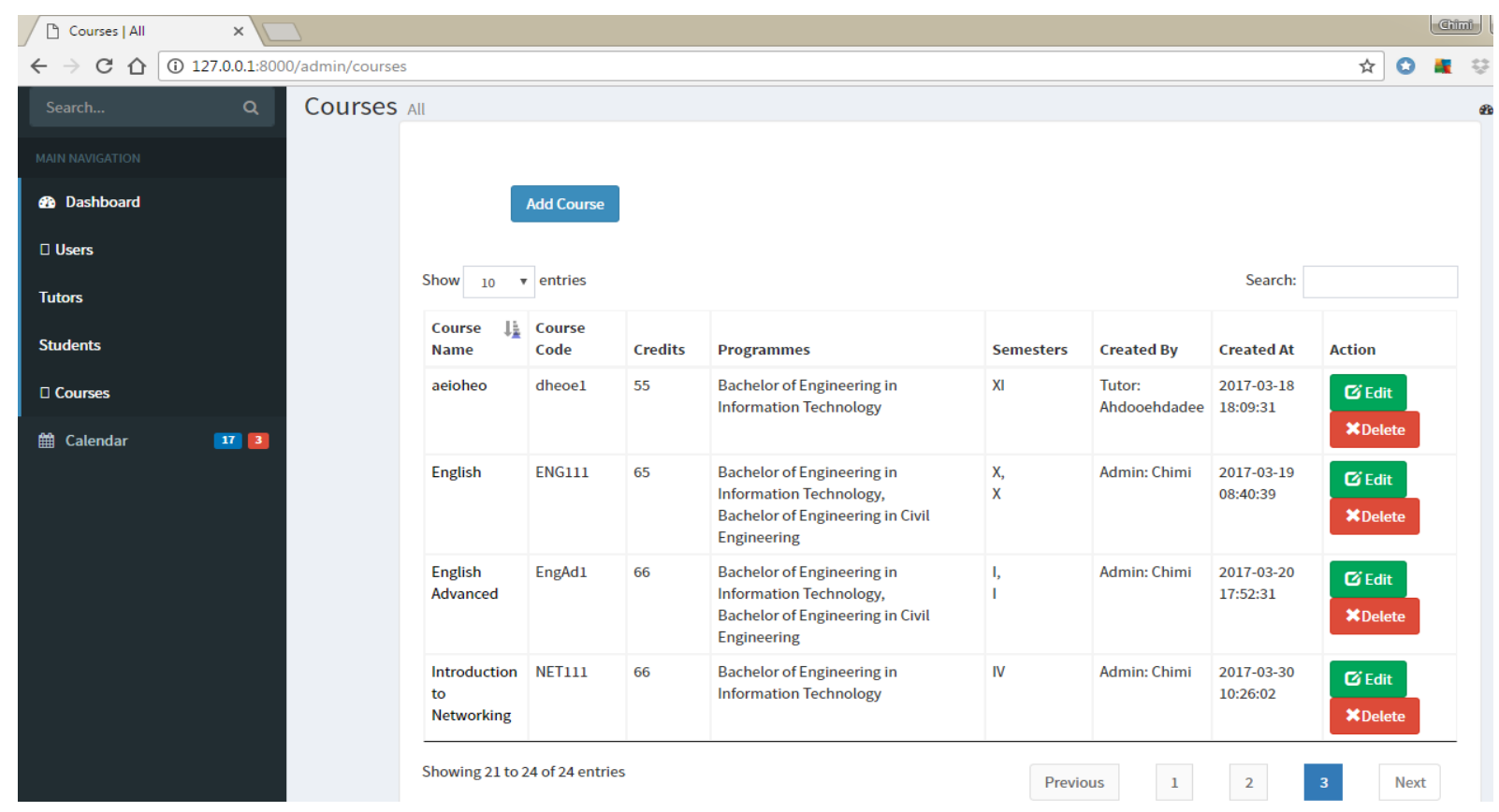

Figure 3. Course List

An ER-diagram that provided the basis to implement normalized database structure for the elearning system is presented on Figure 4.

An use case diagram identifying three actors namely Admin, Tutor and Students is presented on Figure 5. The associated functionalities and the required processes to achieve goals are captured in this diagram. 


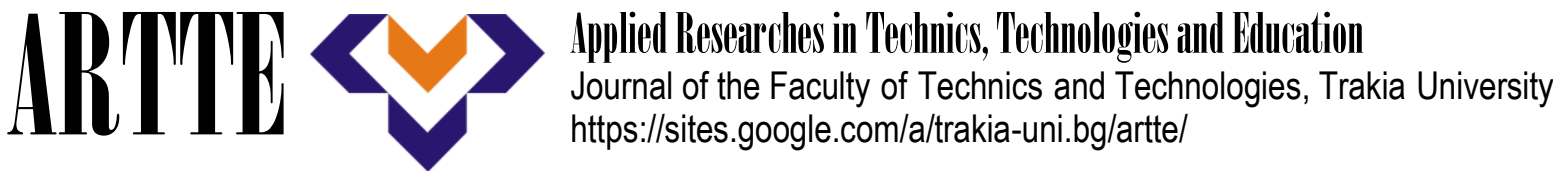

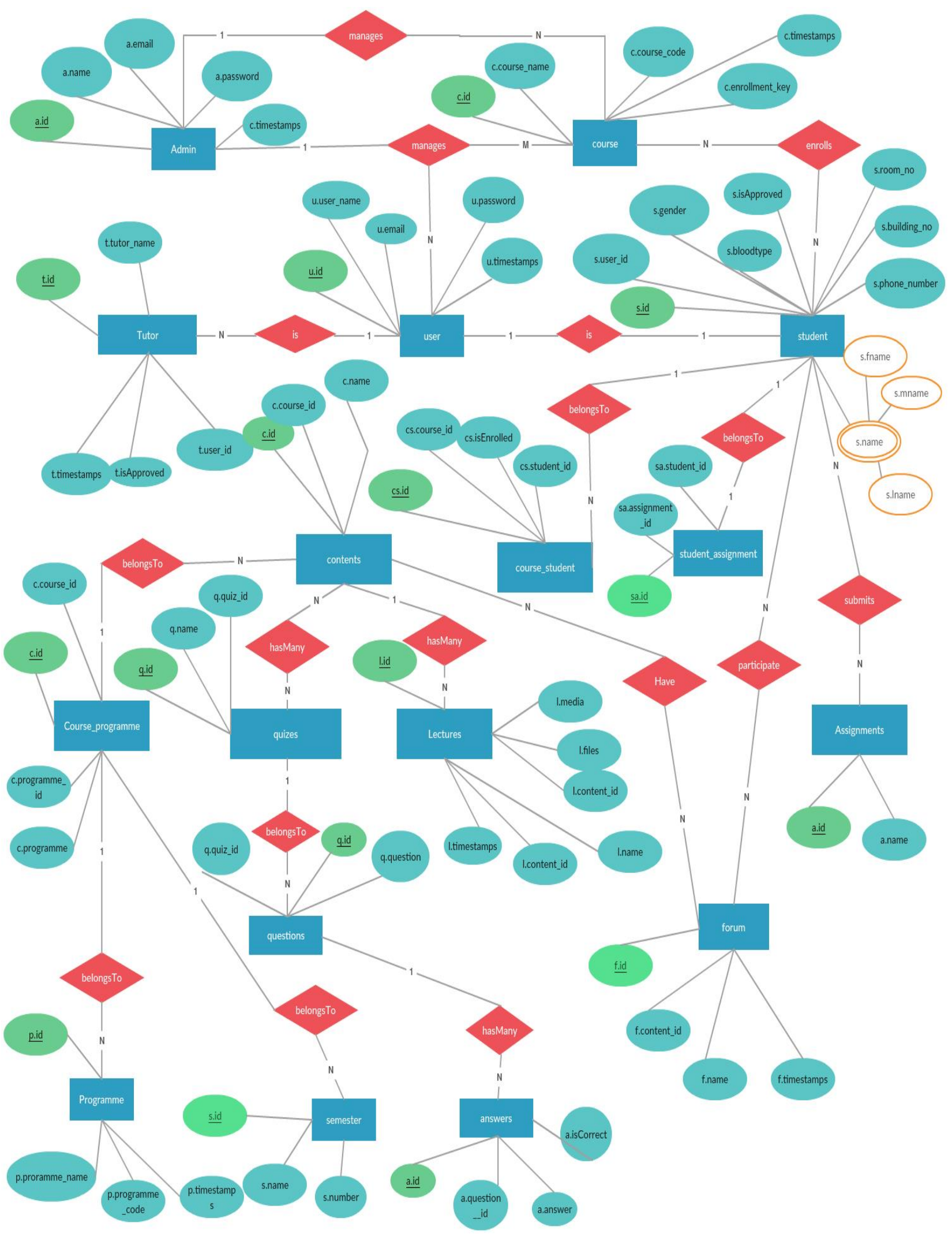

Figure 4. ER-Diagram

IRTIIE Vol. 5, No. 4, 2017 ISSN 1314-8788 (print), ISSN 1314-8796 (online), doi: 10.15547/artte.2017.04.007 


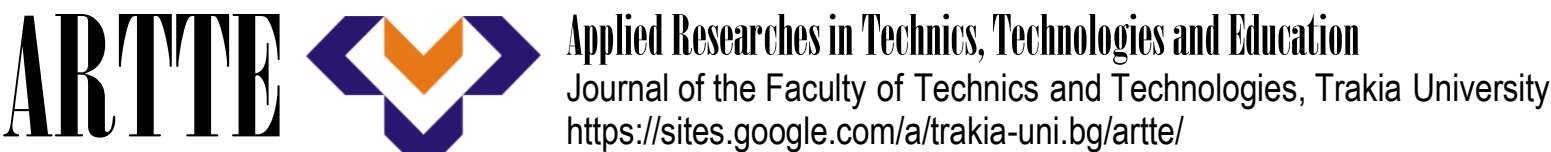

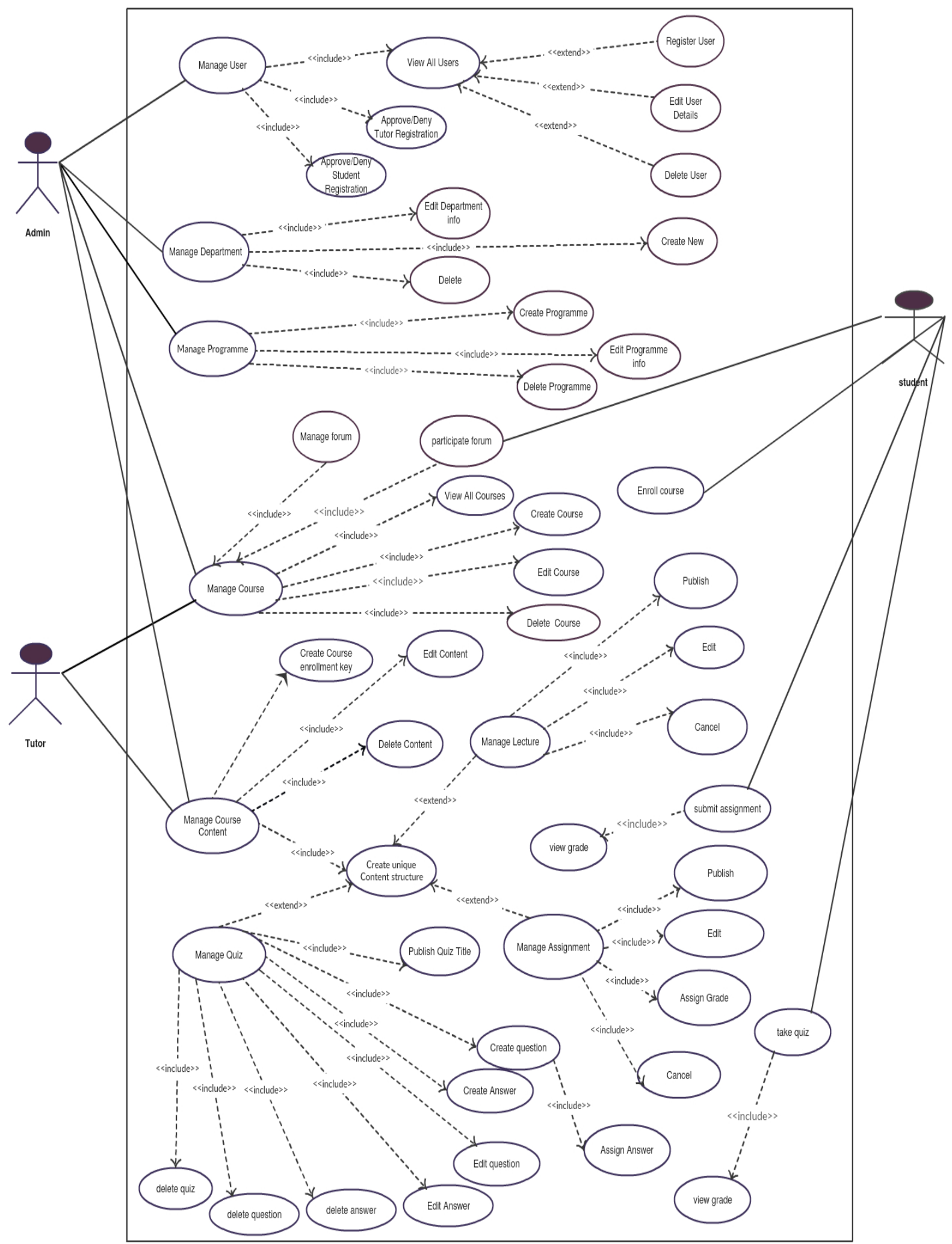

Figure 5. Use Case Diagram

IRTIIE Vol. 5, No. 4, 2017 ISSN 1314-8788 (print), ISSN 1314-8796 (online), doi: 10.15547/artte.2017.04.007 


\section{ARTTIE $Y$}

Ipplied Resseirlohes in Technics, Technologies and Eductition

Journal of the Faculty of Technics and Technologies, Trakia University https://sites.google.com/a/trakia-uni.bg/artte/

Figure 6 displays a simple example of course page with a course titled as 'Networking routing and Switching'. The page includes general information such as hour per day commitment required to complete the course, at which semester is the course being taught and how many ECTs credit does the course have. It displays button to add the content to the course. Each content can be edited or deleted and the various resources (learning materials, forum, assignments, quizzes, etc.) can be assigned to the contents. Admin can view course page for all the courses; however Tutor has privilege to access this page for only the courses that he has created.

The contents do not particularly follow some content structure. It allows easily customizable course structure according to the interest of an university or institution. The course page can be implemented by the university with basic course structure that includes Syllabus, Lectures, Labs Tests, Assignments and Forum. The format to the course structure is unique to the needs of university or an institution. Thus, the system can be used by the schools, institution or the universities [2].

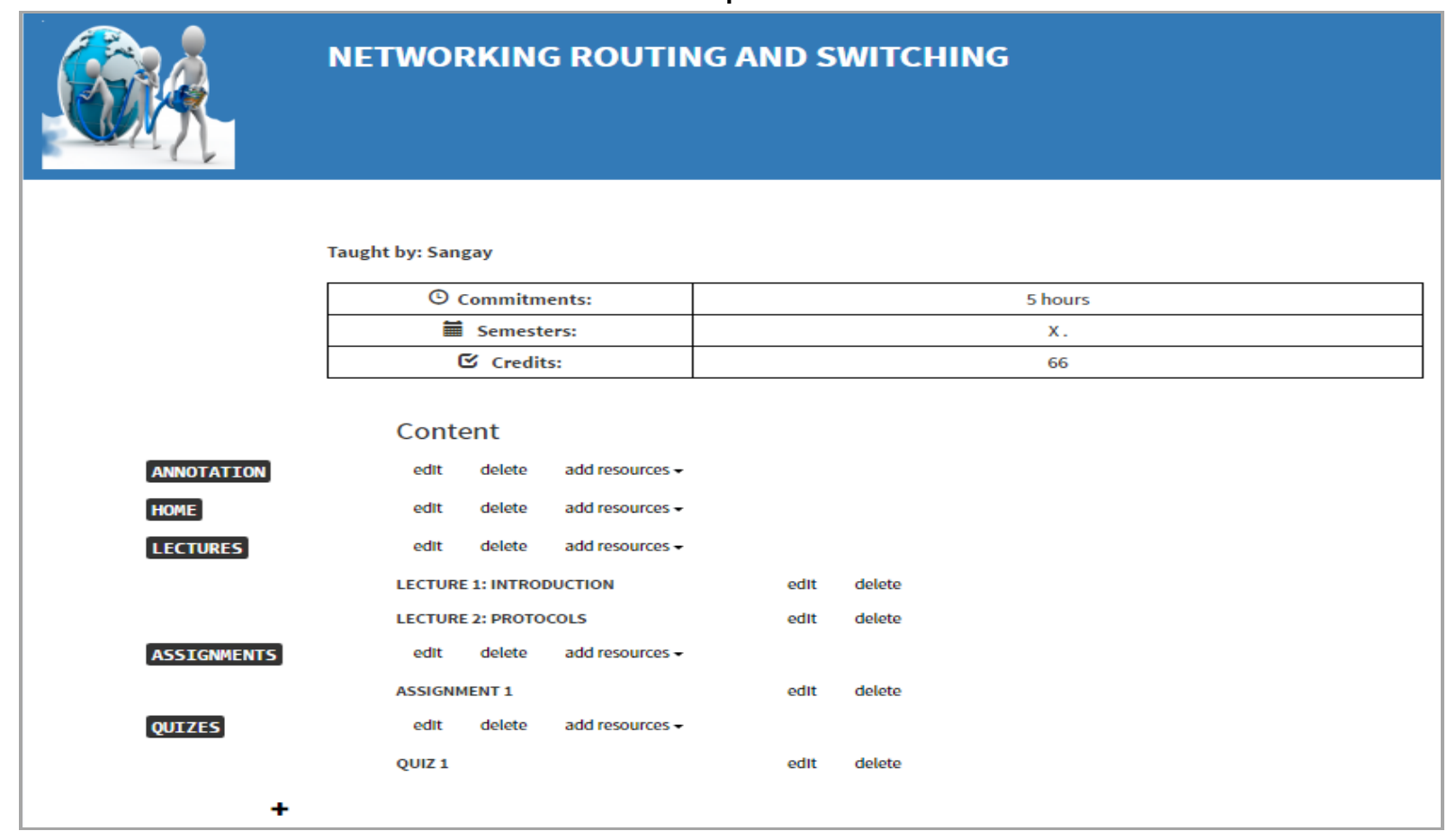

Figure 6. Course Page Example

\section{CONCLUSIONS AND FUTURE WORK}

The effectiveness of online learning was enhanced when learners were able to control the media and information being presented and reflect upon it. This system shall improve the accessibility and collaboration through its easy to use features. One of the vital missions of elearning is to allow people to learn for personal accomplishment or to earn a professional degree, without physically attending a traditional university or academic setting. E-learning can be applied for all levels of schooling from grade school to graduate degrees, and is versatile enough to accommodate all learning styles [14]. The Bhutanese e-learning system facilitates distance learning where people can subscribe to training and learn online. The face-to-face tuitions are supplemented with this system in the form of text, file, audio and video.

IRTIIE Vol. 5, No. 4, 2017 ISSN 1314-8788 (print), ISSN 1314-8796 (online), doi: 10.15547/artte.2017.04.007 


\section{ARTTIE $Y$}

Ipplied Resseirlores in Technics, Technologies and Educration

Journal of the Faculty of Technics and Technologies, Trakia University https://sites.google.com/a/trakia-uni.bg/artte/

Bhutanese E-learning system is required to address the need of distance learning system in parallel to the course taught in regular classes. Although the required modules mainly to create, view and share resources in compliance to the course has been successfully accomplished, this system can be enhanced if it can translated to Bhutanese language. Bhutanese e-learning system is a prototype that can be customized to perform versatile functionalities to engage students and improve their participation. This system also serves as a basic student information system providing details of student, however, development and integration of other functionalities like result management system can be an asset.

\section{REFERENCES}

[1] Baeva, D. C. Learning theories in computer-assisted foreign language acquisition. Proceedings of The science publishing centre «Sociosphere» Conference (No. 9). Vedecko vydavatelske centrum Sociosfera-CZ sro. (2013).

[2] Bhuiyan, T.,Yousuf, K, B., Urmi,S.K., Nahar,A.,\& Ali,N,Y. Development of a web based e-learning system for teaching institution. 3rd International Conference on Intelligent Computational Systems, Singapore. (2013).

[3] Hristov, T., T.Georgiev, A.Smrikarov. A New SCORM Conformable Architecture ot the eLearning Shell (eLSe) Software Platform. Proceedings of the International e-Learning Conference. Brussels, Belgium,Communication \& Cognition, pp. 2.3.1-2.3.8.(2004).

[4] Hua-Yi, Jiann-Gwo Doong, and Xiao-Wei Lin. "The effectiveness of applying moodle Elearning platform on resource classroom students." Computer Science, Technology and Application: Proceedings of the 2016 International Conference on Computer Science, Technology and Application (CSTA2016). World Scientific, (2016).

[5] Jamtsho, Sangay, and Mark Bullen. Distance education in Bhutan: Improving access and quality through ICT use. Distance education 28.2 (2007): 149-161.

[6] Kinley, K. Faculty and students' awareness and challenges of e-learning in a college of education. Journal of the International Society for Teacher Education. 14(1).27-33. (2010).

[7] Murmatsu, K. \& Wangchuk, Y. Current Status of e-learning and its Challenges at Institution of Higher Education in Bhutan. IPSJ SIG Technical Report. Vol.203-CLE-9 No(13). (2013).

[8] Rennie, F., Mason, R. The Development of distributed learning techniques in Bhutan and Nepal. International Review of Research in Open and Distance Learning, Volume 8, Number 1, ISSN 1492-3831. (2007).

[9] Radwan, Nouran M., M. Badr Senousy, and M. Alaa El Din. Current trends and challenges of developing and evaluating learning management systems. International Journal of e-Education, e-Business, e-Management and e-Learning 4.5 (2014): 361.

[10] Rothrauff,L., Ziegmann, M., Hays, J., Canvas LMS Evaluation, Spring and Summer 2013 Report and Recommendations. Canvas Pilot Evaluation Report 2013. (2013).

[11] https://www.talentlms.com/pages/docs/TalentLMS-API-Documentation.pdf -TalentLMS API Documentation.

[12] https://canvas.instructure.com/doc/api/index.html - Canvas API Documentation.

[13] https://laravel.com/docs/5.4/installation -Laravel 5.4 Documentation.

[14] YorulmazA, M., H. Güçlü, Yavuzcan., and Togay, A., Web-based Management System and its Application for Student Design Projects. Journal of Educational and Instructional Studies in the world. (2012): May 2012, Volume: 2 Issue: 2 Article: 26 ISSN: 2146-7463. 